\title{
Antiviral immunity in chronic lymphocytic leukemia measured by anti-rubella antibody
}

\author{
Jadwiga Nowicka ${ }^{1, A-E}$, Piotr Milejski ${ }^{2, A, C, E, F}$, Iwona Urbanowicz ${ }^{3, B-D}$, Przemysław Niewiński ${ }^{2, C, D, F}$ \\ ${ }^{1}$ Department of Clinical Chemistry, Department of Hematology, Wroclaw Medical University, Poland \\ 2 Department of Clinical Pharmacology, Wroclaw Medical University, Poland \\ ${ }^{3}$ Department of Hematology, Wroclaw Medical University, Poland \\ A - research concept and design; $\mathrm{B}$ - collection and/or assembly of data; $\mathrm{C}$ - data analysis and interpretation; \\ $\mathrm{D}$ - writing the article; $\mathrm{E}$ - critical revision of the article; $\mathrm{F}$ - final approval of the article
}

\section{Address for correspondence}

Iwona Urbanowicz

E-mail: iwonaurbanowicz@vp.pl

Funding sources

None declared

Conflict of interest

None declared

Received on December 31, 2016

Reviewed on February 16, 2017

Accepted on August 9, 2018

Published online on January 17, 2019

\section{Abstract}

Background. Chronic lymphocytic leukemia (CLL), the most common form of adult leukemia in Caucasian populations, is characterized by a decrease in anti-infective immunity. Clinical evidence of antiviral immunity decrease is the reactivation of herpes virus in the form of skin lesions. In Europe, rubella infection is common and creates lifelong persistence of $\mathrm{lg} G$ antibodies.

Objectives. The aim of our study was to determine whether hemagglutination inhibition (HAl) rubella test can be used to determine antiviral immunity in CLL patients.

Material and methods. The titers of the HAl test against rubella were examined in a group of 26 healthy subjects, 7 subjects with herpes labialis infection and 56 patients with CLL, among which 9 patients were co-infected with herpes virus.

Results. Statistical tests have shown differences between groups and a significant decrease of the titers of the test in patients with $C L L$, compared with healthy persons and the herpes group compared with other persons.

Conclusions. Our results indicate a significant decrease of antiviral immunity in patients with $C L L$ and persons with herpes-type skin lesions. Simultaneously, relying on our previous studies, we also suggest that the result of this test may be an important indicator of antiviral immunity in patients with CLL.

Key words: chronic lymphocytic leukemia, herpes, antiviral immunity, rubella HAl test

Cite as:

Nowicka J, Milejski P, Urbanowicz I, Niewiński P. Antiviral

immunity in chronic lymphocytic leukemia measured

by anti-rubella antibody. Adv Clin Exp Med. 2019;28(5):

679-682. doi: 10.17219/acem/94164

DOI

$10.17219 /$ acem/94164

Copyright

Copyright by Author(s)

This is an article distributed under the terms of the

Creative Commons Attribution Non-Commercial License

(http://creativecommons.org/licenses/by-nc-nd/4.0/) 


\section{Background}

First line of anti-infectious defense in the innate immune system is composed of receptors that recognize pathogens, which belong to 3 families with a known and recognized function: Toll-like receptors (TLRs), RiG-I - like receptors (RLRs) and nucleotide binding-oligomerization domain (NOD)-like receptors. The early antivirus response is associated with the production of interferons by epithelial cells of the respiratory and digestive systems, dendritic cells that migrate to the lymph nodes, where they stimulate differentiation and activation of lymphocytes $\mathrm{T}$ and $\mathrm{B} .{ }^{1}$ During childhood, the specific antivirus response is generated, which can be measured by appropriate (depending on the kind of virus) methods. Physiological antivirus response may be modified - generally decreased by the neoplastic diseases in the organism.

One of the most common viruses which the organism contacts during childhood, either due to infection or vaccination, is rubella. According to the World Health Organization (WHO), it is estimated that about 94-98\% of the European community contracted the rubella virus, a statistic which can be established with tests using antibodies IgG or IgM against rubella. Neutralizing body titer with the use of agglutination of blood cells under the influence of antibodies has been determined as a test with high specificity. ${ }^{2}$ Hemagglutination inhibition (HAI) method has been recognized by the WHO as the reference rubella antibody method, and the National Committee for Clinical Laboratory Standards (NCCLS) Subcomittee on Rubella Serology in 1992 recommends the use of HAI test as a reference method to establish a calibration standard for other rubella methods. ${ }^{3}$ At the same time, in the evaluation of infection risk, the very low titer of this test is taken into account. ${ }^{4}$ Rubella can produce images of skin lesions similar to measles and the diseases may be differentiated by the simultaneous execution of antibodies against measles and rubella, specific to the recent infection. ${ }^{5}$

The descriptions of rubella infection in patients with chronic lymphocytic leukemia (CLL) are not present in the available literature sources.

On the other hand, the clinical exponent of decreased antiviral immunity is the occurrence of herpes infection, demonstrating reactivation of the virus occurring commonly in the organism. ${ }^{6}$ It may manifest in the form of a cold sore, considered a trivial viral infection, and in relatively more severe forms as a disseminated form, related to the course of nerves, herpes zoster or herpes genitalis. In the retrospective analysis of 125 skin lesions found in 40 persons from among photographically analyzed 750 patients with CLL, beside the most frequently mentioned cancers, other amendments included varicella zoster in 6 and herpes simplex in 3 patients. ${ }^{7}$ In some cases of CLL, herpes virus infection has a rare view of the changes. ${ }^{8,9}$ This infection occurs also in humans generally considered to be healthy, usually in the autumn and winter.

\section{Objectives}

The aim of the present study was to determine whether among previously untreated patients with CLL there is a decrease of antiviral immunity measured using antibodies IgG against rubella with HAI method and thus whether this test can be used to evaluate the antiviral immunity.

\section{Material and methods}

Study was conducted in the group of 56 patients with CLL and included 47 patients (20 women and 27 men) without symptoms of herpes and 9 CLL patients (4 women and 5 men) with symptoms of herpes, aged 36-78 years (median 64 years), previously untreated, with duration of the disease ranging from 1 month to 60 months. According to Rai classification, 13 persons were in the $1^{\text {st }}$ stage of the disease, 29 in the $2^{\text {nd }}, 11$ - in the $3^{\text {rd }}$, and 3 in the $4^{\text {th }}$ clinical stage.

The control group consisted of 33 persons. Twenty-six of them, aged 25-65 years, were healthy persons. Seven, aged 32-67 years, were previously healthy persons, who had herpes. Development of rubella was not observed in any of them.

IgG antibodies against rubella inhibiting hemagglutination were tested using the HAI test called Rubenosticon manufactured by Organon (Oss, the Netherlands). ${ }^{10}$

Test results were compared following the reduced and normal HAI test titer result using Pearson's $\chi^{2}$ test with or without Yates's correction and Fisher's test. The relative risk was also established using odds ratio (OR) calculations with 95\% confidence interval (95\% CI).

Any aspect of the present study that involved patients was conducted with the patient's informed consent and ethical approval from the Ethic Committee of Wroclaw Medical University, Poland.

\section{Results}

In the control group of healthy persons, the test titer was $1: 128$ to $1: 64$ in 25 patients. Only in 1 healthy patient (3.8\%), test titer was reduced to $1: 32 .{ }^{10}$ For 7 persons previously considered to be healthy who had herpes, test titer was reduced in all persons.

Hemagglutination inhibition test titer against rubella was significantly reduced in the group of CLL patients. Values within normal range were present only in 19 persons (40.4\%). For 9 persons with CLL and coexisting herpes infection, test titer in all of them was reduced, except for the case of 1 person. In the group of all 56 CLL patients, normal test titer occurred in 20 patients (35.7\%), and among 33 healthy persons it occurred in 26 persons (78.8\%), which is statistically significantly $(\mathrm{p}<0.005)$ less frequently than in the group of healthy persons, where 
it occurred in 26 persons (78.8\%). The risk of decreased immunity in the group with CLL was 6 times higher $(\mathrm{OR}=6.68)$. Also, CLL group without herpes statistically significantly differed with lower frequency of test values within normal range, compared with the control group ( $\mathrm{p}=0.001)$ and the risk of decreased immunity was 5.5 times higher $(\mathrm{OR}=5.47)$. The control group of healthy persons statistically significantly differed from persons with herpes and all CLL patients with herpes $(\mathrm{p}<0.005)$. Comparison of all tested persons without herpes to all persons with herpes showed a statistically significant difference in the reduction of test titer for patients with herpes and 10-fold risk of reduced antiviral immunity measured with decreased test titer.

Research results are presented in Table 1 and the results of group comparisons, depending on the test titer, are presented in Table 2 .

\section{Discussion}

Chronic lymphocytic leukemia is a disease in which antibacterial, antifungal and antiviral immunity impairment is a consequence of primary immunodeficiency resulting from $B$ lymphocytes dysfunction, which is the reason of hypogammaglobulinemia, inadequate response to the vaccination and complex deficiency of number and function of B lymphocytes, as well as incorrect structure and function of NK cells, neutrophils, monocytes, and complement system. ${ }^{11,12}$ Secondary immune defects result from damage of bone marrow function and treatment-related toxicity. Significant damage of antiviral immunity is usually caused by treatment with purine analogues and with the use of monoclonal antibodies. ${ }^{13,14}$ It is difficult to anticipate which patient will develop the infection. Its occurrence is usually associated with hypogammaglobulinemia and duration of illness. Among numerous risk factors, analyzed by Borthakur et al. in cytomegalovirus (CMV) infections complicating CLL, the reduction of albumins in patients below $3.0 \mathrm{~g} / \mathrm{dL}$ proved to be significant. ${ }^{15}$ According to the current regulations based on the study of resistance to rubella, hemagglutination assay is preferred and test titer $\geq 1: 8$ protects against rubella. ${ }^{3}$

Our previous pilot studies, involving 145 patients with various diseases of the hematopoietic lymphoid tissues, revealed a reduced titer in 7 of 12 of patients with multiple myeloma and in 8 of 15 of patients with CLL - therefore in more than $50 \%$ of persons with lymphoproliferative neoplasms. This proved that in many patients test titer is reduced in relation to the titer obtained in healthy persons. ${ }^{10}$

Our research concerning diseases from the plasma cell clonal diseases involving 60 patients have shown a reduction of test titer in 37 persons, i.e., in $61.6 \%$ of patients, mostly in IgG myeloma, because in $25 / 37$ of patients, there were no statistically significant differences between the average concentrations of immunoglobulins of IgG,
Table 1. Anti-rubella hemagglutination inhibition (HAl) test titers in patients with chronic lymphocytic leukemia (CLL) and in control without/with coexisting herpes infection

\begin{tabular}{|c|c|c|c|c|}
\hline Test titer & CLL & $\begin{array}{c}\text { CLL } \\
+ \text { herpes }\end{array}$ & Control & $\begin{array}{l}\text { Control } \\
+ \text { herpes }\end{array}$ \\
\hline Reduced & 28 & 8 & 1 & 7 \\
\hline $1: 4$ & 1 & - & - & - \\
\hline $1: 8$ & 6 & 2 & - & 3 \\
\hline $1: 16$ & 9 & 3 & - & 3 \\
\hline $1: 32$ & 12 & 3 & 1 & 1 \\
\hline Normal & 19 & 1 & 25 & 0 \\
\hline $1: 64$ & 10 & 1 & 8 & - \\
\hline $1: 128$ & 9 & - & 17 & - \\
\hline Subtotal & 47 & 9 & 26 & 7 \\
\hline Total & \multicolumn{2}{|c|}{56} & \multicolumn{2}{|c|}{33} \\
\hline
\end{tabular}

Table 2. Comparison between groups due to anti-rubella hemagglutination inhibition (HAl) test titer

\begin{tabular}{|c|c|c|c|}
\hline $\begin{array}{l}\text { Compared } \\
\text { group }\end{array}$ & $X^{2}$ test result & $\begin{array}{l}\text { Exact Fisher's } \\
\text { test result }\end{array}$ & $\begin{array}{c}\text { OR } \\
(95 \% \mathrm{Cl})\end{array}$ \\
\hline $\begin{array}{c}\text { t CLL vs t C } \\
\text { titer }<1: 64 \\
\text { titer }<1: 128\end{array}$ & $\begin{array}{l}p<0.005 \\
p=0.001\end{array}$ & $\begin{array}{l}p<0.001 \\
p=0.001\end{array}$ & $\begin{array}{l}6.686(2.502-17.768) \\
5.919(1.973-18.228)\end{array}$ \\
\hline CLL vst C & $p=0.001$ & $p=0.001$ & $5.474(2.008-14.842)$ \\
\hline CLL vs CLLh & $p=0.193$ & $p=0.136$ & $0.184(0.008-1.692)$ \\
\hline $\begin{array}{l}\text { CLL vs } \\
\text { CLLh+Ch }\end{array}$ & $p=0.082$ & $p=0.064$ & $0.211(0.029-1.158)$ \\
\hline $\begin{array}{l}\text { CLL+C vs } \\
\text { CLLh+Ch }\end{array}$ & $p=0.001$ & $p=0.001$ & $0.094(0.014-0.487)$ \\
\hline Cvs Ch & $p<0.005$ & $p<0.005$ & $0.007(0.000-0.166)$ \\
\hline $\begin{array}{l}\text { Cvs } \\
\text { CLLh+Ch }\end{array}$ & $p<0.005$ & $p<0.005$ & $0.006(0.001-0.086)$ \\
\hline
\end{tabular}

C - control; CLLh - chronic lymphocytic leukemia with coexisting herpes infection; Ch - control with coexisting herpes infection; OR - odds ratio; $\mathrm{Cl}$ - confidence interval; CLL - chronic lymphocytic leukemia.

IgA and IgM class compared to the group with normal and reduced test titer. Statistically significant differences occurred, however, in the group of patients with myeloma of IgA class, in which patients with reduced test titer exhibited a higher concentration of IgA and a lower concentration of IgG compared with patients with normal test titer. Among 4 persons with plasma cell clonal diseases, disseminated infections of herpes zoster and low test titer have been reported. ${ }^{16}$ Unexpectedly, low test titer (lower than 1:32) was observed in previously healthy persons who had herpes, same as for healthy persons. Therefore, this titer (1:32) was adopted as a threshold value of the positivity of the test. Current analyzed research results of 56 patients with CLL before treatment revealed test titers in herpes infections both in patients with CLL (CLLh) and in persons considered to be healthy $(\mathrm{Ch})$ in connection with results obtained in previous studies, which allows us to conclude that HAI rubella test may be an important indicator of humoral, especially antiviral, immunity 
in the group of patients with hematological neoplasms. Among patients with these blood cancers, this evaluation is particularly difficult due to the interference of many factors resulting from both disease and therapy. Although HAI test is not currently used in detecting the incidence of rubella, it may be a valuable indicator for the evaluation of the degree of reduction of antiviral immunity. Patients with reduced titer of this test should be special care patients, requiring more frequent control for the presence of virus infections.

\section{Conclusions}

Our results indicate a very significant decrease of antiviral immunity in patients with CLL and persons with herpes-type skin lesions. We believe that drawing attention to other uses of a test which is obsolete and now useless for the diagnosis of infection against rubella may be an important contribution to research on a practical method of determining the degree of impairment of antiviral immunity.

\section{ORCID iDs}

Piotr Milejski (D) https://orcid.org/0000-0001-8929-7469 Iwona Urbanowicz (D) https://orcid.org/0000-0002-9489-322X Przemysław Niewiński (1) https://orcid.org/0000-0002-8016-2805

\section{References}

1. Yokota S, Okabayashi T, Furii N. The battle between virus and host: Modulation of toll-like receptor signaling pathways by virus infection. Mediators of Inflamation. Vol. 2010, article ID 184328. doi:1155/ 2010/184328

2. Arista S, Pistoja D, Titone L, Ammaturia P. Comparison of serological methods for the detection of IgG and IgM antibodies to rubella viruses. Microbiologica. 1987;10:151-160.
3. National Committee for Clinical Laboratory Standards (NCCLS). Evaluation and Performance Criteria for Multiple Component Test Product Intended for the Detection and Quantification of Rubella IgG Antibody: Tentative Guideline, NCCLS Document 1/LA6-T. Villanova: NCCLS, 1992.

4. Goodson JL, Masresha B, Dosseh A, et al. Rubella epidemiology in Africa in the prevaccine era, 2002-2009. J Infect Dis. 2011;204(Suppl 1): S215-225.

5. Siennicka J, Stefanoff P, Rogalska J, Trzcińska A. Etiology of measles suspect cases reported in 2006-2007 in Poland. Przegl Epidemiol. 2011;65(1):39-44.

6. Smith $\mathrm{G}$. Herpes virus transport to the nervous system and back again. Annu Rev Microbiol. 2012;66:153-176.

7. Agnew KL, Ruchlemer R, Catovsky D, Matutes E, Bubker CB. Cutaneous findings in chronic lymphocytic leukemia. Br J Dermatol. 2004; 150(6):1129-1135.

8. Smith E, Hallman JR, Pardasoni A, McMichael A. Multiple herpetic whitlow lesions in a patient with chronic lymphocytic leukemia. Am J Hematol. 2002;69(4):285-288.

9. Romer A, Greiner A, Euk A, Hartschuh W. Herpes simplex vegetans: Atypical genital herpes infection with prominent plasma cell infiltration in B-cell chronic lymphocytic leukemia. J Dtsch Dermatol Ges. 2009;6(10):865-867.

10. Milejski P, Nowicka J, Masiak M, Orzechowska-Juzwenko K, KotlarekHaus S. Rubenosticon in haematological and lymphoreticular disorders [in Polish]. Pol Tyg Lek. 1984;39(24):815-818.

11. Tsiodras S, Samsons G, Keating MJ, Kontoyiannis DP. Infection and immunity in chronic lymphocytic leukemia. Mayo Clin Proc. 2000;75(10):1039-1054.

12. Dearden C. Disease-specific complications of chronic lymphocytic leukemia. Hematology Am Soc Hematol Educ Program. 2008:450-456.

13. Ravandi F, O'Brien S. Infections associated with purine analogs and monoclonal antibodies. Blood Rev. 2005;19(5):253-273.

14. Morrison VA. Infectious complications of chronic lymphocytic leukemia: Pathogenesis, spectrum of infection, preventive approaches. Best Pract Res Clin Haematol. 2010;23(1):145-153.

15. Borthakur G, Lin E, Faderl S, et al. Low serum albumin level is associated with cytomegalovirus reactivation in patients with chronic lymphoproliferative diseases treated with alemtuzumab (Campath-1H)based therapies. Cancer. 2010;110(11):2478-2483.

16. Nowicka J, Milejski P, Orzechowska-Juzwenko K, Unolt J. Rubenosticon test as a marker of depressed humoral immunity in myeloma multiplex. Acta Heamatol Pol. 1997;28:163-168. 